The Open Biomedical Engineering
Journal
CrossMark
Content list available at: www.benthamopen.com/TOBEJ/
DOI: $10.2174 / 1874120701610010113$

\title{
RETRACTION
}

\section{Retraction Notice: The Research on the Impact of Green Beans Sports Drinks on Relieving Fatigue in Sports Training}

Li Qi ${ }^{*}$ and Liu Ying

Shenyang Jianzhu University, China

\section{RETRACTION}

The Publisher and Editor have retracted this article [1] in accordance with good ethical practices. After a thorough investigations we believe that the peer review process was compromised. The article was published on-line on 19-10-2015.

\section{REFERENCES}

[1] L. Qi, and L. Ying, "The research on the impact of green beans sports drinks on relieving fatigue in sports training", Open Biomed. Eng. J., vol. 9, pp. 318-321, 2015.

(C) Qi and Ying; Licensee Bentham Open.

This is an open access article licensed under the terms of the Creative Commons Attribution-Non-Commercial 4.0 International Public License (CC BY-NC 4.0) (https://creativecommons.org/licenses/by-nc/4.0/legalcode), which permits unrestricted, non-commercial use, distribution and reproduction in any medium, provided the work is properly cited.

\footnotetext{
* Address correspondence to this author at the Shenyang Jianzhu University, China; Tel: 18986139113; E-mail: hunter2011@foxmail.com
} 